\title{
Rebel movements in the DRC as sub-national terrorists and the need for appropriate counter initiatives
}

\author{
TNEETHLING
}

\begin{abstract}
The word "terrorism" has been used in various political and policy contexts, and studied in several scholarly disciplines. Most contemporary writing on terrorism focuses on the international dimensions or manifestations of terrorism. However, in Africa, subnational terror (and even state terror) has been a feature of conflict on the African continent. This ranges from amorphous internationally connected groups in which people locally band together around a religious paradigm, to rebels who terrify civilians in civil wars, e.g. the armed movements in the Democratic Republic of the Congo (DRC). Specifically, the north-eastern and eastern parts of the DRC have been major conflict zones where sub-national or domestic terrorists employed and continue to employ terror as a strategy. This paper examines rebel movements in the DRC as a phenomenon of sub-national terrorism - a phenomenon that manifests in life-and-death struggles over access to mineral resources and where there is a clear correlation between conflict and the accumulation of resources.
\end{abstract}

Key words: rebel movements, sub-national terrorism, the DRC (Democratic Republic of Congo), counter-terrorists measures

\section{Introduction}

Despite a commendable effort of the United Nations (UN) since 1999 to bring peace and stability to the Democratic Republic of the Congo, the country continues to face several challenges that pose a constant threat to the fragile transition and consequently, undermine its security. Although the DRC is no longer involved in large-scale armed conflict, it remains a country and society in perpetual turmoil. In the DRC, sometimes described as a "no war, no peace society", there was simply too little progress for a truly transformative peace, particularly in the violent eastern parts. In other words, the ideal of a positive, sustainable (let alone perpetual) peace in the country has largely been a vision encapsulated in paper peace agreements, but had not filtered down to many Congolese citizens' everyday life (Swart 2010: 22-23; Swart 2012: 45, 61). Despite laudable progress in some areas of peacebuilding, the threat or potential outbreak of low-intensity conflict in the eastern DRC remains a reality.

In recent years, several non-state armed movements or militias posed a continuous security threat in the DRC, most notably the Rwandan-rooted Forces Démocratiques de Libération du Rwanda (FDLR) $)^{2}$ and the former Congrès National pour la Défense du Peuple (CNDP), currently functioning as the 'reorganised' M23. Other important armed groups are the

1 Theo Neethling is professor and head of the Department of Political Studies and Governance at the University of the Free State, PO Box 339 (Internal 38), Bloemfontein, 9300, Republic of South Africa.

The FDLR is a group of mainly génocidaires; militias who fled Rwanda in 1994, along with some new recruits. 
Alliance des Patriotes pour un Congo libre et souverain (APCLS) and the Allied Democratic Forces (ADF) in North Kivu, the Lord's Resistance Army (LRA) in the Orientale Province, various Mayi Mayi groups and other smaller movements.

This paper examines rebel movements in the DRC as a manifestation of sub-national terrorism. The DRC is ill-famed for armed movements targeting civilians in order to expel or eradicate segments of the population with the purpose of gaining political and economic control over mineral resources. In the DRC - as in other parts of the post-Cold War international community - a new breed of terrorists came to replace the earlier era of revolutionary and state-terrorism in many parts of the world. Unlike terrorism in the 20th century which could be distinguished from common law crimes and criminal offences because the motivational factor was not financial, conflict and sub-terrorism in the contemporary African context commonly relate to regional and unregulated dynamics, which often make it difficult to distinguish business, government, crime and conflict from one another. Conflicts frequently flow across borders and involve numerous international actors. In the DRC, specifically, terrorism is overwhelmingly of a domestic, sub-national nature, which not only kills, mains and affects millions of people, but also plays out in a regional setting (Cilliers 2003: 91, 93).

\section{Background on the post-electoral (2006) DRC}

It is commonly known that the DRC was politically and socially destabilised by an extremely brutal intra-state war between 1998 and 2003, which was responsible for the death of about 5 million people. Countries emerging from violent conflict carry a high risk of sliding back into violence. The UN therefore, in recent years, significantly expanded its intervention strategies to enhance (post-conflict) peacebuilding (Tull 2010). Since its establishment in 1999, the UN Organisation Mission in the DRC, known as MONUC (for the French Mission de l'Organisation des Nations Unies en République Démocratique du Congo), expanded to the point where it became the world's largest UN peacekeeping mission of recent years, fielding approximately 22000 peacekeepers at the height of its activities in 2010. It can even be argued that MONUC, and its successor mission, MONUSCO (for the French Mission de l'Organisation des Nations Unies en République démocratique du Congo), assumed or at least coassumed some of the responsibilities of the Congolese state. In many instances, the UN served to foster the role of the state, such as protecting civilians against attacks from militias and organised armed movements. In 2006, the UN oversaw an election process designed to take the DRC into a new era of peacebuilding, reconstruction and development (Reuters 2010). Sustained intervention to shore up hard-won but fragile peace included Security Sector Reform (SSR); the disarmament, demobilisation and reintegration (DDR) of combatants; the promotion of human rights; and efforts relating to the protection of civilians.

The 2006 round of democratic elections was without question a huge logistical and political achievement, made possible by the support of MONUC and financing from donors such as the European Union. However, elections did not solve the political problems of the DRC, as rebels or militias continued to destabilise the eastern DRC, principally through the rebels of the Congrès National pour la Défense du Peuple (CNDP), one of the two most institutionalised armed movements in the post electoral DRC. In short, the CNDP defeated the national army whenever it attempted to take them on. The other group, the Forces Démocratiques de Libération du Rwanda (FDLR), mainly génocidaires who fled Rwanda in 1994, along with 
some recruits, also continued to destabilise the DRC through the exploitation of minerals and the creation of no-entry zones where they were in control (Mandrup 2009: 23-25).

In February 2009, the DRC government and rebel CNDP announced that they had negotiated a preliminary agreement addressing the political concerns of the militias. This followed the arrest of the former CNDP leader, General Laurent Nkunda, early in 2009, which resulted in an important agreement between the DRC government and the CNDP (Kahorha 2009). Nkunda's arrest was a significant milestone in the DRC peace process since much of the destabilisation in the eastern parts of the country during the 1990s could be attributed to his destabilising political actions.

A final agreement was signed in March 2009 after a month of negotiations. In terms of the settlement, the CNDP agreed to end its insurgency, transform itself into a political party, and have its fighters join the police or the Congolese army, the Forces Armées de la République Démocratique du Congo (FARDC). In turn, the CNDP obtained a number of concessions such as the release of prisoners, the promulgation of amnesty laws, the creation of a national reconciliation mechanism and the integration of CNDP officials into the North Kivu provincial administration. However, the integration of rebel fighters into the FARDC did not always proceed smoothly. CNDP elements who were dissatisfied with the integration process fled to the hills. Many were unhappy with the dismantling of the militia and the income they received through the CNDP (International Crisis Group 2009).

Attempts to weaken and dismantle the FDLR were even more challenging and the FARDC could only manage to deal with the situation through MONUC's assistance by means of food and logistical support. Although the number of FDLR combatants was reduced by half between 2003 and 2008 with the assistance of MONUC's disarmament, demobilisation, repatriation, reintegration and resettlement (DDRRR) ${ }^{3}$ programme, the FDLR was not seriously damaged (Winter 2009: 2). The organisation continued to pose a threat to the DRC government (Boshoff 2010). FDLR elements (amongst others) were responsible for gross violations of human rights in the form of attacks on civilians and the systematic raping of women (Orievulu 2010).

Another serious challenge for the DRC government in the post-2006 period came from the Lord's Resistance Army (LRA), a guerrilla group originally from northern Uganda, but now residing in the northeastern parts of the DRC. Like the FDLR, the LRA posed a serious threat to civilians in villages and remote areas. This armed force (like the ex-Rwandan génocidaires who entered the DRC from 1994 and who are now mostly grouped in the FDLR) attacked and intimidated civilians since much of their income is derived from taxing the population and from other forms of extortion. Moreover, the government's own army (the FARDC) also posed a threat to civilians. In fact, the army, along with the FDLR and the LRA were the principal threats to civilians in the DRC since 2006 (Winter 2009: 3), and these organisations remain significant political actors in contemporary DRC politics and dynamics (UN Security Council 2012: 20).

As much as some important work was done by the UN in the field of SSR and DDR under challenging circumstances, specifically with regard to the dismantling of the CNDP, the overall security situation in the DRC deteriorated significantly since the establishment of the

This especially concerns the repatriation to Rwanda of surviving members of the génocidaires who fled Rwanda in 1994 and their dependants or offspring.

TD, 10(3), December 2014, pp. 393-408. 
March 23 Movement, commonly known as the M23. The M23 was mainly formed in the early months of 2012 by former members of the CNDP who mutinied against the FARDC (after being integrated) and after having managed to occupy the town of Goma, ${ }^{4}$ the provincial capital of the North Kivu province. Evidence pointed towards cross-border logistical support to the M23 from an old ally of the (former) CNDP, namely the Rwandan government (UN Security Council 2012: 20; Swart 2010: 58). Needless to argue, any painstaking post-conflict programming by international actors, such as the UN, will be severely hampered by the above-mentioned obstacles - which Swart (2010: 45) has described as a "no war, no peace" society. This relates to an environment where institutions, structures, organisations, norms and values that generate conflict potential, both within the society and neighbouring states, are continuously being reproduced. The transformation of the CNDP into the M23 is a good example of this phenomenon.

Another ongoing challenge relates to governance in the DRC. Broadly speaking, Steward (2006: 29) states that many countries have critical gaps in specific areas of governance. Such states possess legal but not actual sovereignty. Moreover, they struggle to maintain a monopoly on the use of force, control their borders, and ensure public order and provide safety to the citizenry. They furthermore lack legitimate governing institutions that can provide effective administration, while the protection of basic rights and freedoms and accountable leadership are generally weak or absent. Few scholars - if any - would argue that the DRC is not such a country. In fact, Herbst and Mills (2013) argue that "[t]he Democratic Republic does not exist" and that the notion that one sovereign power is present in this vast country is "predicated on the Congo myth". They cynically argue that the DRC is not even a failed state; it is a "nonstate". This means that there is a central government, but there is no sovereign power at all outside the urban areas. This effectively leaves about twothirds of the country's estimated 75 million citizens beyond the purview of a central authority. In this context, the DRC - like Somalia - has constantly been topping the list of countries ranked on the Failed State Index while its poor socio-economic conditions are reflected in the fact that it positioned itself at the bottom of the list on the UN Development Index. In view of this Herbst and Mills (2013) even contend that the international community must realise that trying to aid the national government of the DRC is "a bad play". What is needed is a division of the DRC into different states based on a realisation that "there is no such thing as the Congo".

This article is premised on the view that it is highly unlikely that the DRC will be carved up into separate states and that the status quo of the DRC as a unitary state should be accepted as a political given - simply because Africa's leaders do not show any appetite for partitioning the DRC. At the same time, this article accepts as a point of departure that under the current conditions in the $\mathrm{DRC}$, any project by external actors aimed at the reconstruction and development of the DRC or a part thereof will inevitably be facing serious implementation challenges and must be seen as a long term project.

This came to an end in November 2013 when the MONUSCO intervention force forced the M23 out of Goma and other occupied towns. 


\section{Rebels in the DRC as a manifestation of sub-national terrorism}

Broadly speaking, the concept "terrorism" ranges from individual terrorism to state terrorism, to terrorism in national liberation struggles. The word "terrorism" has thus been used in various political and policy contexts, and studied in several scholarly disciplines. It is therefore important to try and define and distinguish between different forms of terrorism for the purpose of this article, which is to study those armed groups in the DRC who have been and are currently responsible for bouts of murderous mayhem in especially the eastern parts of the country.

Terrorism in Africa can generally be defined and understood as "a tactic that uses violence or the threat of violence as a coercive strategy to cause fear and political intimidation... a feature within resistance movements, military coups, political assassinations, and various intra- and inter-state wars that have affected most African states at some point during the continent's transition to independence and subsequent post-colonial period" (Forest and Giroux 2011: 1). This means that terrorism is not an isolated phenomenon on the African continent that has left African states unscathed.

Botha (2008: 30) argues that an act of terrorism includes the following elements:

Intimidation - which is to put fear into force, coerce or induce a government, body, institution or even the general public or segment of the population to perform any act, or adapt/abandon a specific point of view, or act according to/against certain principles.

Disruption - which boils down to disrupting of any public service or the delivery of an essential service or creation of a public emergency.

Creation of insurrection in a state - which is to cause feelings of insecurity among the public or elements thereof, or to induce, cause or spread feelings of terror, fear or panic.

Several scholars and policy analysts have explored the general link between terrorist networks, militias and rebel groups, especially in the post-9/11 period. They argued that illicit transnational networks, particularly terrorist groups, have been very active in weak or socalled failed states. Since the end of the 1990s, African countries have not only struggled against international terrorism, but they have also been challenged by local terrorists who carried out attacks against domestic targets. The 1998 US Embassy bombings in Kenya and Tanzania, and attacks against UN buildings in Nigeria and Algeria, offer just a few examples of international terrorist attacks in African countries, while the Revolutionary United Front (RUF) in Sierra Leone represented a clear case of politically motivated attacks against local communities on African soil. Their methods included the severing of hands, arms and legs of civilians - all in an effort to induce widespread fear and submission in the context typical of African war-torn societies (Forest and Giroux 2011: 6-7).

At least three intersecting trends underlie the contemporary terrorist threat in Africa. First, global geopolitical and economic forces have significantly affected the context for terrorism in Africa. The ending of the Cold War also brought to a close the superpower rivalry of the former Soviet Union and United States on the African continent and thus put a stop to external patronage and financial support for specific political allies. On the negative side, the absence of superpower rivalry sparked internal or intrastate forms of conflict in several African states (Angola being a striking example) and warring parties were compelled to explore alternative sources of funding to undertake and sustain their operations (Duffield 2000: 73). This included the trafficking and illicit trade of small arms and other materials such as mineral resources and narcotics. Second, armed conflict has changed from "being TD, 10(3), December 2014, pp. 393-408. 
primarily inter (between) to intra (within) states". Small, scattered rebel movements and criminal networks (of which Somali piracy is an example) as well as terrorist networks that started to exploit the weaknesses of several post-Cold War African states, gained prominence. Increasingly, armed movements carried out attacks that caused local and sometimes international tremors. Third, the global media environment has undergone significant changes in recent years. Information communication technologies not only established relationships between armed movements and media outlets, but also allowed violent non-state actors to operate within and between the virtual and physical realm. Armed movements of all kinds started to take advantage of the global connections by information technologies such as the mobile phone and access to the Internet for their communications and strategic influence on the economy (Forest and Giroux 2011: 1-11).

Terrorism is not the only type of violence that African states and their citizens have had to grapple with. Famine, drought, endemic poverty, diseases and other natural and human disasters that undermine human security have all been prominent in recent security policy discussions on the African continent (Forest and Giroux 2011: 6-7). However, sub-national terror and even state terror has increasingly become a feature of conflict on the African continent.

At this point of the discussion there is probably a need for a firmer grounding or contextualisation of rebels in the DRC as a manifestation of 'sub-national terrorism'. From all the definitions and propositions on terrorism we derive our own conception of what manifests as terrorism in contemporary Africa. In this regard, we draw from the context of policy and decision-making in the European Union where the concepts of 'sub-national government' and 'multi-level governance' are often used interchangeably. These two concepts basically relate to governments at several territorial tiers, namely supranational, national, regional, local (see Van den Brande 2008). Similarly, in this article, the concept of 'subnational' is applied to and relates to the existence of rebels in African countries as non-state actors at a regional or local level as opposed to state or statutory actors at the national level.

Practically, rebels in the DRC as actors at the regional or local level share similarities with Boko Haram in Nigeria. Political violence in Nigeria is carried out in specific parts of the country, namely the northern parts. In terms of terrain, all the relevant rebel groups occupy a particular area or location - typically in the form of a region - which serves as an operational base to host members and from where they plan their actions and attacks. They usually also receive support from external actors (Forest and Giroux 2011: 3). What is also of interest is that the "new breed of terrorists" on the African continent are basically made up of loose groupings of people with similar backgrounds and beliefs. They are different from the closeknit, disciplined groups of terrorism in the 1980s, but they still show the characteristic of resorting to terror as a way to strike against their enemies (Cilliers 2003: 93).

It is important to note that the armed movements responsible for sub-national terror on the African continent are generally not in a position to present a significant military threat to the relevant governments or are in a position to seize and hold large areas of territory. They fight or settle on the periphery of states and feature in the ongoing violent intrastate conflicts on the African continent (Cilliers and Schüneman, 2013: 4). They range from larger amorphous groups at the local level within a religious motivational framework, e.g. Al Shabab in Somalia or Boko Haram in Nigeria, to rebels who terrify civilians in civil wars, e.g. the armed movements in the DRC. In fact, in Liberia, armed attacks on civilians by both government and rebel forces had become commonplace over the past four decades. Displaced people, who 
had been forced to leave their homes because of the conflict, were particularly vulnerable and harassed by gunmen or militias (Cilliers 2003: 92-94, 96). More recently, the incident on 14 April 2014 in which Boko Haram as an Islamist militant organisation had kidnapped nearly 200 girls from their homes in the rural village of Chibok in the northern parts of the country especially drew worldwide attention. There were also reports of a massacre in the northern towns of Baga and Doro in January 2015 where Boko Haram has been operating for years in the absence of government forces (Crowder 2015). The latter point also applies to the DRC where armed movements act as terrorist organisations - organisations that make use of terror in their actions and insurgencies.

What are the root causes of (sub-national) terrorism in the African context? The answer to this is that there is no simple answer, but a number of factors or variables should be taken into account or considered. It is evident that terrorism differs from one sub-region to another, and one country to another. Fundamentally, at the heart of the problem is the concept of 'state' and the health of political systems on the African continent. In the postcolonial period political power became the ultimate goal, often at any cost. As a result, corruption and nepotism became features of many political systems. Furthermore, draconian or closed political systems emerged; systems that are unable to mediate between state and society. In such contexts, governments that represent the interests of at least the majority of populations are absent. Political marginilisation usually or often follows - which is one of the root causes of domestic terrorism in Africa. Where poor governance and a gap between elites and majorities coincide with factors such as poverty and unemployment, people start to feel that they have nothing to lose. Such conditions could lead to alienation and radicalisation (Botha 2008: 29,35-38) and spark acts of terrorism. In the DRC, many of the abovementioned factors are underlying the political landscape, although the essence of political contestation in post-Cold War DRC has not been that of ideological contestation, but economic consumption (Naidoo 2000: 3). As far as the armed movements in the DRC are concerned, they are able to exploit the weak central authority in the country and this allows them draw funding from (transnational) illicit trade, local resources and banditry, such as the Kivu provinces in the eastern parts of the country (Cilliers and Schünemann 2013:3-4).

Generally, politics in such contexts often evolves into a life-and-death struggle over access to public resources. It becomes a zero-sum game centred around material benefits and in pursuit of influence over followers and competitors. To this end, a high degree of disorder becomes the order of the day, coinciding with a high level of governmental and administrative inefficiency and evidenced by a general disregard for the rules of the formal political and economic sectors. Examples on the African continent in the post-Cold War period relate to imploded political systems such as those in Burundi, Congo-Brazzaville, Sierra Leone, Cote d'Ivoire and the DRC where the result has been destruction of civil societies by ethnoregional violence, massive flows of refugees across borders and rising rates of criminality (Cilliers 2003: 98).

Specifically, as far as the DRC and basically most forms and levels of political power in the country are concerned, control over land implies a ticket to natural resources and therefore economic tensions feed politically motivated hostilities, and vice versa. In simple terms this means that access to resources means the ability to buy arms and reward troops. Troops are needed to secure political power and political power, in turn, guarantees access to land and related resources. This has brought the DRC to the point of being one of the largest humanitarian disasters in the world (Autesserre 2008). 
What makes terrorism such a fearsome phenomenon is that attacks are often aimed at a group, people or symbol that may not directly be linked to their real target. Instead of focusing on a government or ideology, terrorists generally focus on a particular target, such as the intimidation of a specific community or the undermining and damaging of a particular political-economic system. Actions and attacks are not unplanned, although random events may occur to terrorise communities. Moreover, few terrorists believe that single actions, such as the slaughtering of entire villages or the planting of bombs could change a system (Cilliers 2003: 92). To this end, acts of terror usually acquire repetitive properties.

In view of the above, an earlier report of the UN Secretary-General stated that in many armed conflicts

...civilian casualties and the destruction of civilian infrastructure are not simply
byproducts of war, but the consequence of the deliberate targeting of non-combatants.
The violence is frequently perpetrated by non-state actors, including irregular forces and
privately financed militias. In many conflicts, belligerents target civilians in order to
expel or eradicate segments of the population, or for the purpose of hastening military
surrender (UN Secretary-General 1999: 2).

In the DRC, particularly in the eastern parts, persistent high levels of violence and targeted attacks by rebels against civilians have coincided with widespread sexual and gender-based violence, systematic recruitment and use of children by rebels and militias as well as the displacement of significant numbers of civilians, extrajudicial executions and arbitrary arrests (UN Security Council 2013: 2). For instance, the International Crisis Group, in a report on the LRA reported that " $[t]$ he violence of its attacks and the suffering it causes are intended to frighten villagers into not giving [their] pursuers the information they need to wage a counter-insurgency campaign and to frighten civilians away so they can move with less chance of being spotted" (IRIN 2010).

Since the end of the 1990s, several actors - including the UN - continually reported on the deep and widespread humanitarian consequences of the extreme brutality and acts of terror committed by rebels and militias in the DRC. The following excerpt illustrates the magnitude of sub-national terrorism and consequential insecurity in the DRC (UN Secretary-General 2013: 6):

The total estimated number of internally displaced persons in the Democratic Republic of the Congo stood at 2.6 million as at 31 August [2013]. North Kivu, with over 1 million internally displaced persons, and South Kivu, with over 700,000, remained the most affected provinces, accounting for some 65 per cent of the total. In Maniema, the number of internally displaced persons exceeded 200,000 on 31 July, mainly owing to fighting spilling over from South Kivu. In Katanga, the number of internally displaced persons continued to increase since June 2012 as a result of the activity of armed groups; around 370,000 internally displaced persons were registered in that province as at 31 August.

Theoretically, Naidoo correctly points out that the ideological motivation underlying an armed conflict is largely unimportant to rebels groups in conflicts where control of natural resources are concerned. What matters is whether the rebels can sustain themselves financially (Naidoo 2000: 3). This is different from ideologically-inspired violent non-state groups that are sometimes responsible for murderous mayhem in several parts of the world 
(Forest and Giroux, 2011) and financial motivations are certainly true for at least the most powerful, armed movements in the DRC, namely the M23 and the (Rwandan-rooted) FDLR.

In the DRC most of the gold mined in the country is dug up by artisanal and small-scale miners. These miners work in very dangerous conditions, particularly in rebel-held parts of the country Gold sourcing has important consequences on the issue of armed group financing (International Peace Information Centre 2013). The FDLR always generated much of its funding from illegal mining activities (UN Security Council 2011: 2). Minerals such as gold, but also cassiterite, coltan and wolframite, generated estimated profits of millions of dollars for the FDLR (Arimatsu and Mistry 2012:16). Likewise, the M23 rebel group took control of a profitable portion of the "conflict gold trade" in the eastern DRC since its formation in 2012, until the MONUSCO Intervention Force forcibly ended its reign in Goma, North Kivu in November 2013. The revenue from the illicit trade was used to fund its military campaign and the M23 worked closely with other local armed groups in gold-rich territories to smuggle gold to Uganda as well as Burundi from where it is sold internationally.

Much of the smuggled gold from the DRC is initially sold in the United Arab Emirates from where it is mainly handed on to India and Switzerland. In recent years, gold seemed to be the most important conflict mineral in the eastern DRC with at least 12 tons worth roughly $\$ 500$, smuggled out of the eastern DRC every year (All Africa.com 2013). However, unlike the FDLR and the M23, the LRA does not seem to prey on the DRC's mineral resources, but rely on abductions and child labour for cultivating food. In the case of the LRA, abducted civilians are often used as porters, while the women are forced into sexual slavery (VOA News 2012). In this regard, they share certain similarities with the Abu Sayyaf rebels in the Philippines who, in the absence of natural resources to exploit, turned to kidnapping instead (Naidoo 2000: 3).

In the broader context, one should be acutely aware of the fact that the absence of a functioning, nationally recognised central government in Kinshasa, the eastern and northeastern parts of DRC especially became safe havens and facilitating environments for domestic terrorism. Cilliers strikingly argues that the more informal the nature of local political and economic transactions, the easier it becomes to use the political and economic domains for 'other' hidden activities. In such a context, the distinction between legal and criminal, as well as between politics, business and corruption, is opaque. In the DRC - a large territory comparable to Western Europe - hidden and informal networks have always been associated with rebel groups and the ability to access arms and supplies (Cilliers 2006: 100). Fukuyama's contention that neopatrimonialism has arisen on the African continent because a powerful private sector is absent, is certainly applicable to considerable parts of the DRC. The way to make money is by acquiring political power and then distributing the rents that could be accessed as a result. In Fukuyama's words: “The answer to why this happened is clear: poor governance. For contrast, you can look at successful countries in East Asia which have coherent and effective state bureaucracies" (Fukuyama 2013: 2). All of the above should be taken into consideration in counter-terrorism strategies and will be further discussed in the section below. 


\section{Pursuing a positive outcome in the DRC}

Premised on the work of Lancaster et al (2011:4), one of the following (three) approaches could be pursued when engaging or dealing with rebel movements or domestic terrorism in the DRC:

Firstly, in accordance with the "statebuilding school", rebel movements should be viewed as a law-and-order issue that could be reduced to irrelevance in relatively small portions of land where small-scale banditry has in any event, over many years, constituted their primary business. Secondly, in accordance with the "military solution school", rebel movements have no longer any political significance or meaning in a democratic political framework. This calls for intervention and justifies the use of force on the battlefield. Thirdly, in accordance with the "re-engagement school", dialogue with rebel leaders should be pursued because past military action against the rebel movements triggered and spread violence against local populations.

Currently, the international community as represented by relevant UN functionaries seems to pursue a mix of all three above-mentioned approaches. Realising the importance of statebuilding, UN Security Council Resolution 2098 provides for the current UN peacekeeping mission, MONUSCO, to continue its work in the field of stabilisation by establishing "functional state security institutions" in the DRC, and by strengthening of the country's democratic order to reduce the risk of instability. The resolution also supports the establishment of a minimum level of sustainable state authority and control in the conflictaffected areas of the eastern DRC. This includes efforts to improve security, state authority and socio-economic recovery. In addition to statebuilding efforts, the UN is committed to prevent the expansion of all armed groups, and, in fact, to neutralise these groups and disarm them, specifically through the MONUSCO Intervention Brigade, which was mandated by the UN Security Council in March 2013 to contribute to the objective of reducing the threat posed by these groups to state authority.

The MONUSCO Intervention Force is tasked to carry out "targeted offensive actions", either jointly with the DRC armed forces or unilaterally in a robust and highly mobile and versatile manner (UN Security Council 2013: 6-8). At the coalface MONUSCO force commander General Carlos Alberto dos Santos Cruz put matters in perspective when he declared that " $[\mathrm{r}]$ ight now military force is important. In this country, everyone picks up a gun to achieve their objective. We have a plan to take action against all armed groups without exception" (as quoted by Hofstatter and Oatway 2013: 4).

A series of spectacular victories over the M23 in November 2013 has led the UN Special Representative for the DRC, Martin Kobler, to declare the M23 dead. Within days of the M23's defeat, civilian administration was installed in Goma, and it was decided that no taxes would be collected until 2014 (Wolters 2013). This coincided with General dos Santos Cruz's statement that "we need more than military action... There must be benefits for the population, such as healthcare, education and public services. If these issues are not dealt with there will be another rebellion" (as quoted by Hofstatter and Oatway 2013: 4).

The move to create the Intervention Force has been described as an "unprecedented move" to respond and "neutralise" ongoing violence in the DCR. The UN's resolution is bold in that it was the UN's first calling for offensive action by a peacekeeping mission. A specialist unit within the 20000 -strong MONUSCO peacekeeping mission was authorised to enforce rather than keep the peace (Hagan 2013). At the same time, UN Security Council Resolution 
2098 committed the UN Special Representative for the DRC to promote inclusive and transparent political dialogue among all Congolese stakeholders. This had been done with a view to furthering reconciliation and democratisation and to encourage the organisation of transparent and credible provincial and local elections (UN Security Council 2013: 8). Unfortunately, at the time of writing the UN has been criticised for not doing very much to put a lid on rebel activities in the eastern parts of the DRC. This happened after about 200 civilians, including women and children, have been killed north of Goma in the Beni territory of the North Kivu province. MONUSCO bases have even been attacked by the local population for not coming to their defence. However, this time around the M23 and the FDLR were not responsible for attacks on civilians, but the Allied Democratic Forces (ADF), an armed group originally from Uganda (Fabricius 2014).

The question arises whether outside involvement in the DRC makes things better or worse. The answer may well be premised on the view that it is always extremely difficult to work in ungoverned areas since problems could multiply exponentially if authority were to be imposed under external or foreign pressure. In the worst case, it may even undermine the legitimacy of the very regime that the action intends to bolster. Critics correctly argue that anti-terrorism legislation forced down the throats of weak or dysfunctional criminal justice systems in African states is of limited or little value in situations where economic failure continues. No military operation can make states such as the DRC safe without a functional, nationally recognised central government. What should be pursued are multiple initiatives and measures to combat acts of terror where safe havens and facilitating environments become the general arrangement (Solomon 2013: 440; Cilliers 2006: 70). Moreover, any effort or model from the outside to render assistance on the basis of "capacity building" would not be effective unless it facilitates "legitimacy building", i.e. that the local population should view the central government as legitimate and worthy of their support (Lamb 2013).

Solomon critically comments that international actors involved in counter-terrorism on the African continent need to adopt a more sophisticated perspective on the nature of the threat posed by terrorism. Apart from distinguishing between international terrorism and subnational terrorism, counter-terrorism measures should focus on the root causes driving terrorism and acts of terror. Root causes relate to issues of underdevelopment, poverty, poor governance and the dearth of justice. Therefore, measures to improve democratic governance and enhance responsive governance should supplement the establishment of military and security institutions in African states suffering from acts of terror. It requires "a strategy designed to foster the creation of more democratic space and ultimately more inclusive polities" (Solomon 2013: 439-441).

At the same time, Forest and Giroux correctly argue that the limitations of a typical African government's ability to effectively combat terrorist attacks should be recognised - particularly where terrorists have transnational linkages. Where they operate in "ungoverned spaces" or "lawless areas" within a country's borders sub-national terrorism becomes extremely difficult, if not impossible, to combat as the case of the DRC clearly illustrates. This makes crossnational collaboration in countering terrorism an imperative, as well as the need for African nations to participate in multinational efforts and initiatives - the latter being a growing tendency in the African context (Forest and Giroux 2011: 12-13).

Thus direct encouragement and assistance to the central government of the country in question - in this case the DRC - in exercising and extending (better) control over so-called ungoverned areas are probably (still) the best way of approaching any course of action 
(Institute for National Strategic Studies 2009: 104). This, of course, implies a search for long-term solutions because the strengthening of state capacity - facilitating statebuilding and security governance - is certainly one of the most demanding and challenging endeavours in current-day international affairs.

In accordance with Solomon's assertion that the military should take a back seat to political, diplomatic and economic dimensions in counter-terrorism measures (Solomon 2013: 440), Williams even suggests that UN peacekeeping operations could usefully realign their 'protection of civilian strategies' to help build resilient local communities. In effect, this implies processes designed to empower civilian populations to gain a bigger say in their national government structures, which further implies the use of peacekeepers as peacebuilders. To this end, Williams is convinced that civil empowerment is one of the best ways over the longer term to reduce both violence and the risk of future wars (Williams 2013: $1-2)$.

The above-mentioned coincides with Agbiboa's research on Boko Haram in Nigeria and his findings that countries fighting terrorism must learn that a war on terror can never address the underlying conditions that shape armed movements who reject the prevailing order and develop radical positions, or opt for the violent action. Accordingly, actors fighting domestic terrorists should know that a "security-only military approach" is a war without end, which usually turns into a vicious cycle of terror. It even radicalises terrorist groups and strengthens the collective resolve of its members and thus threats of violence or prison are rarely effective deterrents. An effective counterterrorism policy and strategy should appreciate the broader context in which violent actions or attacks occur and seek to meaningfully and non-violently alter it (Agbiboa 2013: 68).

\section{Conclusion}

Many or most observers of international politics would agree with Herbst and Mills (2013) when they state that "[i]f there is a prize for the worst place on Earth, Congo has a strong claim". The country has been severely affected by sub-national terrorism - a phenomenon that is intimately linked to the failure to effect sustained development and to consolidate accountable and effective governance. The absence of good governance creates opportunities for armed organisations to employ terror as a strategy. To this end, sub-national terrorists have turned the north-eastern and eastern parts of the DRC into major conflict zones. In the DRC all the above-mentioned movements relied heavily, but not exclusively, on the use of extreme violence against civilians in pursuing their objectives (Cilliers 2006: 58-59).

As far as the main thrust of this study is concerned, the view taken in this article supports the scholarly insight and argument that in countries such as the DRC, militias are filling power vacuums that have been caused by the inability and lack of military capacity of weak states to fight the militias effectively. This is certainly true for the two most institutionalised rebel groups of recent years, the M23 and the FRDL, as well as other armed groups, such as the APCLS and the ADF in North Kivu, and the Mayi-Mayi groups - based on the fact that the DRC government had not been able to control large parts of the country since the early 1990s (Mandrup 2009: 16).

Clearly, there is a link between conflict and the accumulation of resources which has been particularly evident in the activities of the M23 and the FDLR. This means that the dominant non-state actors in the DRC use their positions to maintain or pursue control over 
economic resources, specifically mineral resources. Moreover, the ability of rebels to draw funding from illicit trade and the exploitation of natural resources make it extremely difficult to put an end to the cycles of conflict in the eastern parts of the country (Cilliers and Schüneman, 2013: 4). This is exacerbated by the fact that conflicts such as those in the DRC are often rooted in or linked to external factors, and that they often have considerable extrinsic or regional dimensions (Smith 2009: 279).

The phenomenon of rebel movements in the DRC further reiterates the scholarly contention that the nation-state in many parts of the international community is under pressure. It certainly highlights and confirms the point that states are no longer the only important actors and that non-state entities have also become significant actors. Generally, where governments are not in control of the lengths and breadths of the geographical territories that constitute their countries or states - arguably the basic requirement for territorial sovereignty aggrieved national groups in the form of sub-national terrorists often appear and press upward, mostly brutally and violently. In the DRC the direct extension of state authority remains a pressing issue and one that has created numerous problems on a national as well as a broader transnational level. To this end, external counter-terrorism measures in countries such as the DRC should avoid a too state-centric and militaristic approach to counter rebels as manifestations of sub-national terrorism, but at the same time do enough to support and enable African governments to confront the threat of terrorism more effectively.

This is easier said than done, however, because the DRC has received an enormous $\$ 27$ billion in the field of development assistance between 2000 and 2013. This certainly makes the DRC one of the world's largest recipients of international assistance. Moreover, the country hosts one of the UN's largest peacekeeping missions for almost a decade and a half. Yet, critics can rightly argue that this has not helped much, at least in part because donors have effectively rewarded the central government's failure to rule, and ignored corruption (Herbsts and Mills 2013).

In the final analysis, this article supports the view of Autesserre (2008) that peacebuilding efforts should continue and that local peace will be sustainable only if the Congolese state is stable and its institutions are built up at all levels. Post-conflict efforts and related counterterrorism tasks will obviously be extremely difficult tasks given the magnitude of challenges such as weak state institutions, a fragmented political arena, high refugee flows, and poor infrastructure. In the words of Autesserre (2008): "When it comes to Congo, international actors should work, quite literally, from the ground up" - a project that requires a long-term vision, patience and sustainability.

\section{Acknowledgement}

This work is based upon research supported by the National Research Foundation in Pretoria, South Africa. Any opinion, findings and conclusions or recommendations expressed in this material are those of the author and therefore the NRF does not accept any liability in regard thereto. 


\section{References}

African Union (2011) African Union's policy on reconstruction and development of post-conflict countries, <http://www.africa-union.org/root/AU/AUC/Departments/PSC/PCRD/ PCRD\%20Main\%20Web\%20Source/index.html>, accessed 17 October 2011.

Agbiboa, D.E. (2013) 'Is might right? Boko Haram, the Joint Military Task Force, and the Global Jihad'. Military and Strategic Studies 5(3):53-72.

All Africa.com (2013) 'Congo-Kinshasha: Striking gold - how M23 and its allies are infiltrating Congo's gold trade', <allafrica.com/stories/201310100873.html>, accessed 10 October 2013.

Arimatsu, L. and Mistry, H. (2012) 'Conflict minerals: The search for a normative framework', Chatham House International Law Programme Paper, IL PP 2012/01, September.

Autesserre, S. (2008) 'The trouble with Congo', Foreign Affairs, May/June 2008, $<\mathrm{http}: / /$ www.foreignaffairs.com/articles/63401/s\%C3\%83\%C2\%A9verineautesserre/the-trouble-with-congo>, 29 January 2015.

Boshoff, H. (2010) 'MONUC to leave the DRC, mission unaccomplished', AfricaFiles, 26 April, <www.africafiles.org/article.asp?ID=23475>, accessed 12 October 2010.

Botha, A. (2008) 'Challenges in understanding terrorism in Africa', African Security Review 17(2): 29,36-38.

Cilliers, J. (2003) 'Terrorism in Africa', African Security Review 12(4): 91-103.

Cilliers, J (2006) 'Africa, root causes and the "war on terror", African Security Review 15(3): $58-71$.

Cilliers, J. and Schüneman, J. (2013). 'The future of intrastate conflict in Africa: More violence or greater peace?' ISS Paper No. 246, May: 1-24.

Crowder, N. (2015) 'The enemy within: Boko Haram's reign of terror across Northern Nigeria', Washington Post, 26 January 2015, <http://www.washingtonpost.com/news/in-sight/wp/2015/01/26/the-enemy-withinboko-harams-reign-of-terror-across-northern-nigeria-part-i/>, accessed 28 January 2015.

Duffield, M. (2000) 'Globalisation, transborder trade, and war economies', in Berdal, M. and Malone, D.M. (eds.), Greed and Grievance: Economic Agendas in Civil Wards, London: Lynne Rienner: 69-90.

Fabricius, P. (2014) 'Is the Force Intervention Brigade neutral?', ISS Today, 27 November 2014.

Forest, J.J.F. and Giroux, J. (2011) 'Terrorism and political violence in Africa: Contemporary trends in a shifting terrain', Perspectives on Terrorism 5(3-4): 1-17.

Fukuyama, F. (2013) 'The role of politics in development', CDE Insight, August: 1-6.

Hagan, J. (2013) 'Congo Intervention Brigade will see UN forces go on the offense', $<$ http://www.policymic.com/articles/31825/congo-intervention-brigade-will-see-unforces-go-on-the-offense>, accessed 13 October 2013. 
Herbst, J. and Mills, G. (2013) 'The invisible state: It's time we admit the Democratic of Congo does not exist', Foreign Policy, 24 June 2013, <http://foreignpolicy.com/2013/06/24/the-invisible-state/>, accessed 29 January 2015.

Hofstatter, S. and Oatway, J. (2013) 'DRC on brink of war again', Sunday Times, 10 November.

International Crisis Group (2009) 'Conflict in Congo', 16 June, <www.crisisgroup.org.home/index.cfm?id=2829>, accessed 3 February 2010.

International Peace Information Service (2013) 'Analysis of the interactive map of artisanal mining areas in eastern DR Congo', IPIS, November, <http://www.ipisresearch.be/publications_detail.php?id=428>, accessed 11 May 2014.

Institute for National Strategic Studies (2009) Global Strategic Assessment 2009, Washington DC: National Defence University.

IRIN (2010) 'Minor rebels, major terror', 5 May, <http://www.irinnews.org/report/89034/drcminor-rebels-major-terror>, accessed 6 November 2013.

Kahorha, J. (2009) 'DR Congo: Refugee return heightens North Kivu tensions', ReliefWeb, 22 December, <www.reliefweb.int/rw/rwb.nsf/db900sid/SNAA7Z26QR?OpenDocument>, accessed 25 January 2010.

Lamb, R.D. (2008) 'Ungoverned areas and safe heavens', Small Wars Journal Blog, 20 June, <http://smallwarsjournal.com/blog/ungoverned-areas-and-safe-havens>, accessed 22 October 2013.

Lancaster, P., Lacaille, G. and Cakaj, L. (2011) 'Diagnostic study of the Lord's Resistance Army', International Working Group on the LRA, 11 June.

Mandrup, T. (2009) 'Rumble in the jungle - private sources of security or order and disorder: The case of the D.R. Congo', Paper delivered at a conference, On strategy: future challenges for Africa, Stellenbosch University, South Africa, 11-12 June.

Naidoo, S. (2000) 'The role of natural resources in conflict', A presentation made at the International Ministerial Diamond Conference, Pretoria, 20 September.

Orievulu, K. (2010) 'Security situation in the DRC: A case of weak state leaning on the UN', Consultancy Africa Intelligence, $16 \quad$ September, $<$ www.consultancyafrica.com/index.php?option $=$ com_content\&view $=$ article\&id $=542$ : security-situation-in-the-drc-a-case-of-a-weak-state-leaning-on-theun\&catid $=60$ :conflict-terrorism-discussion-papers\&Itemid $=265>, \quad$ accessed $\quad 12$ October 2010.

Reuters (2010) 'UN's DRC trip dominated by peacekeepers' exit', 16 April, <www.alertnet.org/thenews/newsdesk/LDE63E1OT.htm>, accessed October 2010.

Smith, K. (2009) 'Has Africa got anything to say: African contributions to the theoretical development of International Relations', The Round Table: The Commonwealth Journal of International Affairs 98(402), June: 269-284.

Solomon, H. (2013) 'The African state and the failure of US counter-terrorism initiatives in Africa: The cases of Nigeria and Mali', South African Journal of International Affairs 20(3): 427-445. 
Steward, P. (2006). 'Weak states and global threats: Fact or fiction', The Washington Quarterly, Spring.

Swart, G. (2010) 'Introduction: A vanquished peace?', In Swart, G. (ed.), A Vanquished Peace: Prospects for the Successful Reconstruction of the Democratic Republic of Congo, London: Adonis \& Abbey.

Swart, G. (2012) 'A vanquished peace: The success and failure of conflict mediation in the Democratic Republic of Congo', Southern African Peace and Security Studies 1(1): 4363.

Tull, D. (2010) 'When they overstay their welcome: UN peacekeepers in Africa', SWP Comment, June.

UN Security Council (2011) Resolution 2021 (2011), adopted by the Security Council at its 6671st meeting, on 29 November 2012, UN Headquarters: New York.

UN Security Council (2012) Resolution 2053 (2012), adopted by the Security Council at its 6792nd meeting, on 27 June 2012, New York: UN Headquarters.

UN Security Council (2013) Resolution 2098 (2013), adopted by the Security Council at its $6943^{\text {rd }}$ meeting, on 28 March, New York: UN Headquarters.

UN Secretary-General (1999) Report of the Secretary-General to the Security Council on the protection of civilians in armed conflicts, S/1999/957, 8 September, New York: UN Headquarters.

UN Secretary-General (2011) Report of the Secretary-General on the United Nations Organisation Stabilisation Mission to the Democratic Republic of Congo, S2011/298, 12 May, New York: UN Headquarters.

UN Secretary-General (2013) Report of the Secretary-General on the United Nations Organisation Stabilisation Mission in the Democratic Republic of the Congo, S/2013/581, 30 September, New York: UN Headquarters.

VOA News (2012) 'Thousands flee LRA attacks in Congo', 5 March, $<$ http://www.voanews.com/content/thousands-flee-lra-attacks-in-congo141575123/179271.html>, accessed 25 October 2012.

VOA News (2013) 'M23 rebels in DRC: Using illegal gold to finance rebellion', 10 October, <http://www.voanews.com/content/report-drcs-m23-using-illegal-gold-to-financerebellion/1767096.html>, accessed 10 October 2013.

Williams, P. (2013) 'Protection, resilience and empowerment: United Nations peacekeeping and violence against civilians in contemporary war zones', Politics 33(4): 287-298.

Winter, P. (2009) 'Peacekeeping, protection and stabilisation in the DRC', Paper delivered at a conference, On strategy: Future challenges for Africa, Stellenbosch University, 11-12 June.

Van den Brande, K. (2008) 'The role of the subnational level of government in decisionmaking for sustainable development', Paper written in the framework of project 4, 'The Flemish Sustainable Development Policy and Multilateral Decision-Making", Institute for International and European Policy, Katholieke Universiteit Leuven. 